\title{
Optimasi Bentuk Penopang Pelat Beton Apung
}

\author{
HAZAIRIN, ERMA DESMALIANA, IMAS ANGGI MEYLANI \\ Program Studi Teknik Sipil Institut Teknologi Nasional Bandung \\ Email: herin@itenas.ac.id
}

\begin{abstract}
ABSTRAK
Bencana banjir seringkali terjadi di Indonesia, bahkan Istana negara tidak luput terendam karena tidak terbendungnya volume air yang meningkat. Kerusakan yang terjadi pada sarana dan prasarana akibat banjir tidaklah kecil dan satu cara untuk menghindari kerusakan tersebut yaitu dengan menggunakan pelat beton apung. Pemodelan pelat beton apung di atas fondasi elastis menggunakan perangkat lunak Ansys, dengan nilai tumpuan elastis sebesar $10 \mathrm{kN} / \mathrm{m}^{3}$ dan beban sebesar $2.500 \mathrm{~N}$ pada bagian ujung pelat beton apung. Penelitian ini bertujuan untuk mengetahui pengaruh bentuk penopang pelat beton apung terhadap keseimbangan apung, serta nilai deformasi maksimum akibat pembebanan. Pelat beton apung berukuran $3 \times 4$ meter dengan variasi bentuk penopang segitiga, trapesium dan lengkung baik satu arah maupun dua arah. Dari hasil analisis dan pembahasan dapat disimpulkan bahwa pelat beton apung dengan bentuk penopang segitiga $30^{\circ}$ dua arah memiliki nilai deformasi terkecil sebesar 0,194 m; volume pelat sebesar 9,328 $\mathrm{m}^{3}$ serta deviasi draft sebesar 0,191 $\mathrm{m}$.
\end{abstract}

Kata Kunci : pelat beton apung, bentuk penopang pelat, deformasi

\begin{abstract}
Flood disasters often occur in Indonesia, even the state palace is not spared from being submerged because the increasing volume of water cannot be stopped. The damage that occurs to facilities and infrastructure due to flooding is not small and one way to avoid this damage is to use floating concrete slabs. Modeling of floating concrete slab on an elastic foundation using Ansys software, with an elastic support value of $10 \mathrm{kN} / \mathrm{m}^{3}$ and a load of 2,500 N at the end of the floating concrete slab. This study aims to determine the effect of the shape of the floating concrete slab support on the buoyancy balance, as well as the maximum deformation value due to loading. Floating concrete slab measuring $3 \times 4$ meters with various forms of triangular, trapezoidal and curved supports in one direction or two directions. From the results of the analysis and discussion, it can be concluded that the floating concrete slab with a triangular shape of 300 two-way supports has the smallest deformation value of $0.194 \mathrm{~m}$, the plate volume is $9.328 \mathrm{~m}^{3}$ and the draft deviation is $0.191 \mathrm{~m}$.
\end{abstract}

Keywords : floating concrete plate, plate support geometry, deformation 


\section{PENDAhUlUAN}

Curah hujan yang cukup tinggi serta luasnya daerah perairan di Indonesia dapat mengakibatkan bencana banjir. Bencana banjir sangat merugikan bagi masyarakat dan juga pemerintah dengan rusaknya sarana dan prasrana yang dapat mengganggu stabilitas perekonomian secara signifikan, sehingga pencegahan-pencegahan bencana banjir harus segera dilakukan. Salah satu alternatif yang dapat digunakan untuk mengantisipasi kerusakan sarana yaitu dengan menggunakan struktur beton apung. Bentuk pelat beton apung yang sering digunakan adalah pelat persegi, yang mana pelat ini hanya akan stabil apabila dibebani oleh beban merata dengan posisi sentris. Oleh karena itu, maka akan dilakukan penelitian bentuk penopang pelat beton apung yang berbeda-beda. Pelat beton apung ini akan dimodelkan menggunakan perangkat lunak Ansys untuk mendapatkan nilai deformasi maksimum, yang kemudian diverifikasi dengan perhitungan manual secara teoritis menggunakan teori kesetimbangan benda apung untuk mengetahui kestabilan pelat beton apung setelah dibebani. Pelat beton apung sudah pernah dibahas dan diteliti oleh penelitian terdahulu, dimana penelitian tersebut membahas tentang kapasitas lentur pelat beton apung dengan bentuk penopang persegi.

\section{TINJAUAN PUSTAKA}

\subsection{Beton apung}

Beton apung merupakan jenis beton yang memiliki kepadatan kurang dari air dan mengapung di atas air. Beton terapung (floating concrete) dapat diklasifikasikan sebagai kapal berupa kendaraan air dengan bentuk dan jenis tertentu, yang digerakan dengan tenaga angin, tenaga mekanik, energi lainnya, ditarik atau ditunda, termasuk kendaraan yang berdaya dukung dinamis, kendaraan di bawah permukaan air, serta alat apung dan bangunan terapung yang tidak berpindah-pindah (UU RI No.17 Tahun 2008 tentang Pelayaran, Pasal 1 angka 36).

\subsection{Beton Sandwich}

Beton sandwich merupakan beton yang terdiri dari dua lapisan tipis, kaku dan kuat dari material padat yang dipisahkan oleh satu lapisan tebal yang terbuat dari material dengan berat jenis yang rendah, yang memiliki kekakuan dan kekuatan yang lebih rendah dari lapisan pengapitnya (Callister, W.D., 1997). Dua lapisan tipis yang terdapat pada struktur sandwich ini disebut dengan lapisan wajah (faces), dan satu lapisan tengah disebut dengan lapisan inti (core) seperti tertera pada Gambar 1. Seringkali beton sandwich yang efisien didapatkan apabila berat inti dari sandwich kira-kira sama dengan jumlah berat lapisan pengapitnya.

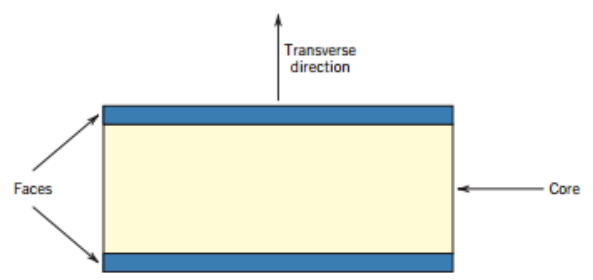

\section{Gambar 1. Beton sandwich (Sumber: Callister, W. D., 1997)}

\subsection{Gaya Apung}

Gaya apung adalah kemampuan suatu benda untuk dapat mengapung dalam cairan ataupun fluida. Gaya apung biasanya terjadi akibat adanya perbedaan tekanan fluida pada kedalaman yang berbeda. Benda yang berada di dalam air akan memiliki massa yang lebih kecil dibandingkan saat benda tidak berada dalam air. Hal ini disebabkan karena adanya gaya apung 
yang menekan ke atas searah dengan gaya angkat sehingga benda tersebut menjadi lebih ringan. Benda yang dimasukkan ke dalam fluida akan mengalami perbedaan tekanan antara fluida bagian atas dan fluida bagian bawah. Fluida yang terletak pada bagian bawah benda memiliki tekanan yang lebih besar daripada fluida yang berada di bagian atas benda. Gaya yang bekerja pada benda yang terendam di dalam air seperti tertera pada Gambar 1 berikut.

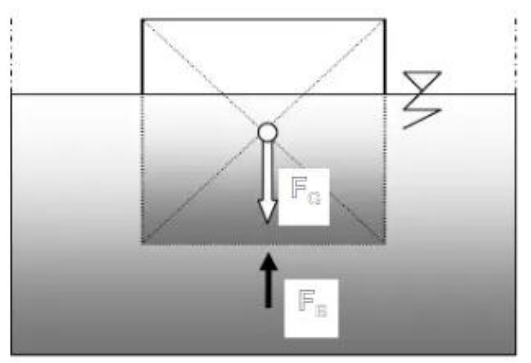

Gambar 1. Gaya-gaya yang bekerja pada benda yang terendam dalam air (Sumber: academia.edu/6347762/MEKANIKA FLUIDA)

Gaya apung $\left(F_{G}\right)$ ditentukan dengan menggunakan Persamaan 1.a hingga Persamaan 1.e berikut:

$$
\begin{aligned}
& F_{G}=F_{B} \\
\leftrightarrow & F_{B}=W_{b}-W_{a} \\
\leftrightarrow & F_{G}=\rho_{b} x g x V_{b} \\
\leftrightarrow & F_{B}=\rho_{a} x g x V_{b t} \\
\leftrightarrow & \rho_{a} x g x V_{b t}=\rho_{b} x g x V_{b}
\end{aligned}
$$

halmana:

$F_{B}=$ force bouyancy / gaya apung [N],

$F_{G}=$ force gravity / gaya gravitasi [N],

$W_{b}=$ berat benda di udara [N],

$W_{a}=$ berat benda dalam air [N],

$\rho_{a}=$ berat jenis air $\left[1.000 \mathrm{~kg} / \mathrm{m}^{3}\right]$

$\rho_{b}=$ berat jenis benda $\left[\mathrm{kg} / \mathrm{m}^{3}\right]$,

$g=$ gravitasi bumi $\left[9,81 \mathrm{~m} / \mathrm{s}^{2}\right]$,

$V_{b}=$ volume benda $\left[\mathrm{m}^{3}\right]$,

$V_{b t}=$ volume benda terendam $\left[\mathrm{m}^{3}\right]$.

\subsection{Kesetimbangan Benda Apung}

Kestabilan benda terjadi apabila benda tersebut diusik atau dibebani, maka benda tersebut dapat kembali ke posisi kesetimbangan awalnya. Kesetimbangan benda terapung sesuai dengan Prinsip Hukum Archimedes, yaitu benda yang terapung akan mengalami gaya apung sebesar zat cair yang dipindahkan. Stabilitas benda terapung dapat diketahui berdasarkan tinggi metasentrumnya. Titik metasentrum merupakan titik potong antara garis vertikal melalui pusat apung benda setelah digoyangkan dengan garis vertikal melalui berat benda sebelum digoyangkan. Tinggi metasentrum seperti tertera pada Gambar $\mathbf{2}$ dan kesetimbangan benda terapung tertera pada Gambar 3 berikut. 


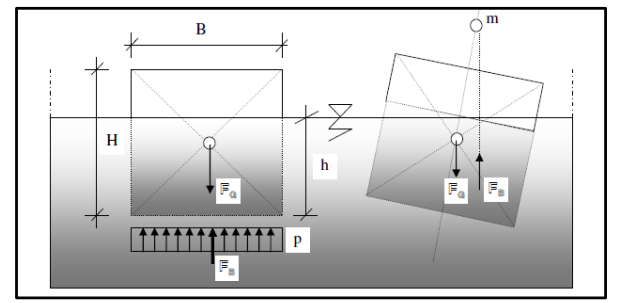

Gambar 2. Tinggi metasentrum

(Sumber: academia.edu/6347762/MEKANIKA FLUIDA)

Tinggi metasentrum $(m)$ ditentukan dengan Persamaan 2 berikut:

$$
m=\frac{I_{0}}{V}-\overline{A_{0} B_{0}}
$$

halmana:

$I_{0} \quad=$ momen inersia tampang benda yang terpotong permukaan zat cair $\left[\mathrm{mm}^{4}\right]$,

$\mathrm{V} \quad=$ volume zat cair yang dipindahkan $\left[\mathrm{m}^{3}\right]$,

$\overline{A_{0} B_{0}} \quad=$ jarak antara pusat apung dan pusat benda [m].

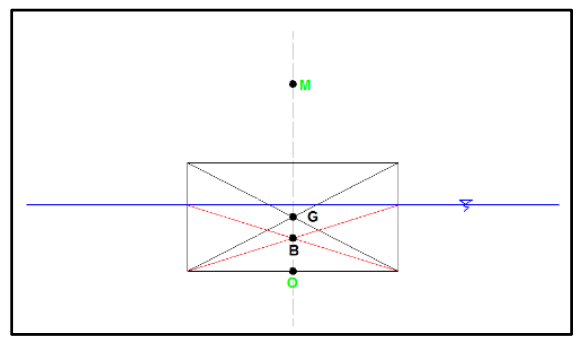

\section{Gambar 3. Kesetimbangan benda terapung}

Jarak titik pusat berat benda ke titik metasentrum $(M)$ ditentukan dengan Persamaan 3.a hingga Persamaan 3.b:

$$
\begin{aligned}
& B G=O G-O B \\
& B M=\frac{I_{0}}{\text { Volume benda terendam }} \\
& G M=B M-B G
\end{aligned}
$$

halmana:

$O=$ titik dasar benda,

$B \quad=$ titik pusat apung benda terendam,

$G \quad=$ titik pusat berat benda,

$M \quad=$ titik metasentrum,

$B G \quad=$ jarak antara titik pusat apung dengan titik pusat berat benda [m],

$O G \quad=$ jarak antara dasar benda ketitik pusat berat benda [m],

$O B=$ jarak antara dasar benda ketitik pusat apung $[\mathrm{m}]$,

$B M=$ jarak titik pusat apung ketitik metasentrum [m],

$G M=$ jarak titik pusat berat benda ketitik metasentrum [m].

Apabila:

$G M>0 \rightarrow$ benda stabil.

$G M=0 \rightarrow$ benda dalam stabilitas netral.

$G M<0 \rightarrow$ benda tidak stabil. 


\section{METODOLOGI PENELITIAN}

\subsection{Kajian Pustaka}

Kajian pustaka merupakan tahap awal mencari referensi yang sesuai dengan bahasan penelitian ini. Buku peraturan dan jurnal akan menjadi dasar dan pedoman selama proses penelitian ini berlangsung, diantaranya SNI 03-2847-2002 Persyaratan Beton Struktural Untuk Bangunan Gedung dan Sejenisnya.

\subsection{Perhitungan Teoritis Pelat Beton Apung Sebelum Dibebani}

Perhitungan secara teoritis menggunakan teori kesetimbangan benda apung bertujuan untuk menentukan tinggi tenggelam pelat beton apung atau letak muka air pada saat pelat beton apung sebelum dibebani.

\subsection{Pemodelan Menggunakan Software Ansys}

Software yang digunakan dalam penelitian ini yaitu Ansys. Pelat beton apung dimodelkan dengan menggunakan aplikasi AutoCAD 3D yang kemudian di-export ke Ansys. Pelat beton apung dimodelkan dengan sudah menentukan letak muka air.

\subsection{Input Data}

Parameter pelat beton apung antara lain dimensi pelat $3 \times 4$ meter; berat jenis pelat $600 \mathrm{~kg} / \mathrm{m}^{3}$; jenis material pelat; nilai kekakuan pondasi $E S=10 \mathrm{kN} / \mathrm{m}^{3}$; serta beban $\mathrm{P}=2.500 \mathrm{~N}$ di-input ke dalam aplikasi Ansys. Beban P diletakkan pada ujung pelat beton apung untuk mendapatkan nilai deformasi maksimum. SetUp pemodelan pelat beton apung seperti pada Gambar $\mathbf{4}$ dan Gambar 5 berikut.

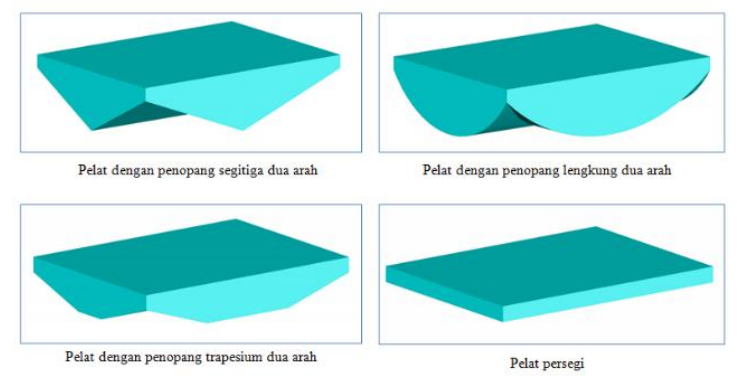

Gambar 4. Pemodelan bentuk penopang pelat beton apung

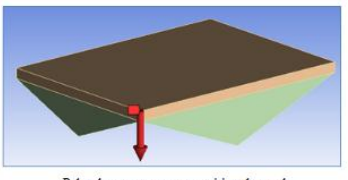

Pelar dengan penopang segitiga dua aral

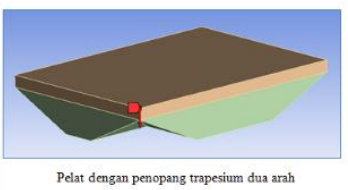

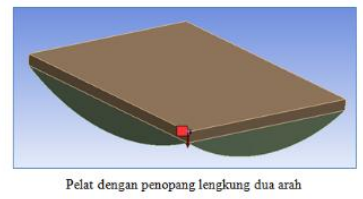

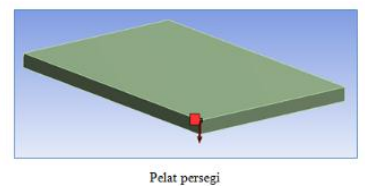

Gambar 5. SetUp pembebanan pada pelat beton apung

\subsection{Solve}

Solve atau hasil output dari perhitungan menggunakan aplikasi Ansys adalah total deformation, yang mana hasil tersebut akan menunjukkan deformasi maksimum dan minimum pada setiap pelat beton apung yang diteliti. Proses running dilakukan apabila semua parameter serta beban pada pelat beton apung sudah di-input. 


\subsection{Perhitungan Teoritis Pelat Beton Apung Setelah Dibebani}

Perhitungan teoritis menggunakan teori kesetimbangan benda apung kembali dilakukan setelah proses perhitungan menggunakan aplikasi Ansys selesai dan menghasilkan nilai deformasi maksimum. Perhitungan teoritis ini bertujuan untuk mengetahui keseimbangan pelat beton apung setelah dibebani.

\subsection{Pembahasan}

Pembahasan dari penelitian dilakukan setelah semua perhitungan selesai. Pembahasan berisi analisis nilai total deformasi yang dihasilkan oleh setiap pelat beton apung, perbandingan volume pelat beton apung dan juga deviasi tinggi tenggelam pelat beton apung baik sebelum maupun sesudah dibebani. Hal ini bertujuan untuk menentukan bentuk penopang pelat beton apung yang paling baik, stabil dan efisien.

\subsection{Kesimpulan}

Kesimpulan berisi tentang hasil akhir dari pembahasan dan menentukan bentuk penopang pelat beton apung yang paling stabil dan efisien.

\section{HASIL PENELITIAN DAN PEMBAHASAN}

\subsection{Umum}

Penelitian ini dilakukan dengan memodelkan pelat beton apung dalam beberapa bentuk berbeda yang akan diberi beban $\mathrm{P}=2.500 \mathrm{~N}$ pada ujung pelat beton apung dan diletakkan pada pondasi elastis dengan elastic support $\mathrm{ES}=10 \mathrm{kN} / \mathrm{m}^{3}$. Bentuk penopang pelat beton apung yang diamati adalah segitiga, trapesium, lengkung dan pelat persegi.

\subsection{Perhitungan Teoritis Sebelum Pelat Beton Apung Dibebani}

Data-data perencanaan pelat betong apung dengan bentuk penopang segitiga $15^{\circ}$ satu arah:

Volume pelat $\left(V_{b}\right)$

Berat jenis pelat $\left(\rho_{b}\right)$

Berat jenis air $\left(\rho_{a}\right)$

Gaya gravitasi bumi $(g)$

Tinggi keseluran pelat $(H)$

$$
\begin{aligned}
& =4,8115 \mathrm{~m}^{3} \\
& =600 \mathrm{~kg} / \mathrm{m}^{3} \\
& =1000 \mathrm{~kg} / \mathrm{m}^{3} \\
& =9,81 \mathrm{~m} / \mathrm{s}^{2} \\
& =0,6019 \mathrm{~m}
\end{aligned}
$$

Menghitung volume pelat beton apung terendam $\left(V_{b t}\right)$

$$
\begin{aligned}
& F_{G}=F_{B} \\
& \rho_{b} \times g \times V_{b}=\rho_{a} \times g \times V_{b t} \\
& 600 \times 9,81 \times 4,8115=1.000 \times 9,81 \times V_{b t} \\
& V_{b t}=2,8869 \mathrm{~m}^{3}
\end{aligned}
$$

Menghitung volume pelat beton apung di atas air $\left(V_{b a}\right)$

$$
\begin{aligned}
& V_{b a}=V_{b}-V_{b t} \\
& V_{b a}=4,8115-2,8869 \\
& V_{b a}=1,9246 \mathrm{~m}^{3}
\end{aligned}
$$

Menghitung tinggi pelat beton apung di atas air $(t)$

$$
\begin{aligned}
t & =\frac{V_{b a}}{b \times h} \\
t & =\frac{1,9246}{3 \times 4} \\
t & =0,1604 \mathrm{~m}
\end{aligned}
$$


Menghitung tinggi pelat beton apung tenggelam/draft $(d)$

$$
\begin{aligned}
& d=H-t \\
& d=0,6019-0,1604 \\
& d=0,4415 \mathrm{~m}
\end{aligned}
$$

Jadi, dari hasil perhitungan pelat beton apung dengan bentuk penopang segitiga $15^{\circ}$ satu arah didapatkan tinggi benda tenggelam adalah 0,4415 meter.

Hasil perhitungan tinggi tenggelam pelat beton apung dengan berbagai variasi bentuk penopang disajikan pada Tabel 1 hingga Tabel 5.

Tabel 1. Hasil Perhitungan Tinggi Tenggelam Pelat Beton Apung dengan Bentuk Penopang Segitiga Satu Arah

\begin{tabular}{cccccccccc}
\hline Sudut & $\boldsymbol{\rho}_{\boldsymbol{b}}$ & $\boldsymbol{\rho}_{\boldsymbol{a}}$ & $\boldsymbol{g}$ & $\boldsymbol{V}_{\boldsymbol{b}}$ & $\boldsymbol{V}_{\boldsymbol{b} \boldsymbol{t}}$ & $\boldsymbol{V}_{\boldsymbol{b} \boldsymbol{a}}$ & $\boldsymbol{t}$ & $\boldsymbol{H}$ & $\boldsymbol{d}$ \\
\hline $\left.\mathbf{[}^{\mathbf{0}}\right]$ & {$\left[\mathbf{~ k g / \mathbf { m } ^ { \mathbf { 3 } } ]}\right.$} & {$\left[\mathbf{~ k g} / \mathbf{m}^{\mathbf{3}}\right]$} & {$\left[\mathbf{~ m} / \mathbf{s}^{\mathbf{2}}\right]$} & {$\left[\mathbf{m}^{\mathbf{3}}\right]$} & {$\left[\mathbf{m}^{\mathbf{3}}\right]$} & {$\left[\mathbf{m}^{\mathbf{3}}\right]$} & {$[\mathbf{m}]$} & {$[\mathbf{m}]$} & {$[\mathbf{m}]$} \\
\hline 15 & 600 & 1.000 & 9,81 & 4,812 & 2,887 & 1,925 & 0,160 & 0,602 & 0,442 \\
\hline 20 & 600 & 1.000 & 9,81 & 5,676 & 3,405 & 2,270 & 0,189 & 0,746 & 0,557 \\
\hline 25 & 600 & 1.000 & 9,81 & 6,597 & 3,958 & 2,639 & 0,220 & 0,890 & 0,689 \\
\hline 30 & 600 & 1.000 & 9,81 & 7,596 & 4,558 & 3,039 & 0,253 & 1,066 & 0,813 \\
\hline 35 & 600 & 1.000 & 9,81 & 8,702 & 5,221 & 3,481 & 0,290 & 1,250 & 0,960 \\
\hline 40 & 600 & 1.000 & 9,81 & 9,952 & 5,971 & 3,981 & 0,332 & 1,459 & 1,127 \\
\hline 45 & 600 & 1.000 & 9,81 & 11,400 & 6,840 & 4,560 & 0,380 & 1,700 & 1,320 \\
\hline
\end{tabular}

Tabel 2. Hasil Perhitungan Tinggi Tenggelam Pelat Beton Apung dengan Bentuk Penopang Trapesium Satu Arah

\begin{tabular}{cccccccccc}
\hline Sudut & $\boldsymbol{\rho}_{\boldsymbol{b}}$ & $\boldsymbol{\rho}_{\boldsymbol{a}}$ & $\boldsymbol{g}$ & $\boldsymbol{V}_{\boldsymbol{b}}$ & $\boldsymbol{V}_{\boldsymbol{b t}}$ & $\boldsymbol{V}_{\boldsymbol{b a}}$ & $\boldsymbol{t}$ & $\boldsymbol{H}$ & $\boldsymbol{d}$ \\
\hline$\left[\mathbf{0}^{\mathbf{}}\right]$ & {$\left[\mathbf{~ k g} / \mathbf{m}^{\mathbf{3}}\right]$} & {$\left[\mathbf{~ k g} / \mathbf{m}^{\mathbf{3}}\right]$} & {$\left[\mathbf{~} \mathbf{/} \mathbf{s}^{\mathbf{2}}\right]$} & {$\left[\mathbf{m}^{\mathbf{3}}\right]$} & {$\left[\mathbf{m}^{\mathbf{3}}\right]$} & {$\left[\mathbf{m}^{\mathbf{3}}\right]$} & {$[\mathbf{m}]$} & {$[\mathbf{m}]$} & {$[\mathbf{m}]$} \\
\hline 15 & 600 & 1.000 & 9,81 & 4,715 & 2,829 & 1,886 & 0,157 & 0,522 & 0,364 \\
\hline 20 & 600 & 1.000 & 9,81 & 5,545 & 3,327 & 2,218 & 0,185 & 0,637 & 0,452 \\
\hline 25 & 600 & 1.000 & 9,81 & 6,429 & 3,858 & 2,572 & 0,214 & 0,760 & 0,545 \\
\hline 30 & 600 & 1.000 & 9,81 & 7,388 & 4,433 & 2,955 & 0,246 & 0,893 & 0,647 \\
\hline 35 & 600 & 1.000 & 9,81 & 8,449 & 5,070 & 3,380 & 0,282 & 1,040 & 0,759 \\
\hline 40 & 600 & 1.000 & 9,81 & 9,650 & 5,790 & 3,860 & 0,322 & 1,207 & 0,885 \\
\hline 45 & 600 & 1.000 & 9,81 & 11,040 & 6,624 & 4,416 & 0,368 & 1,400 & 1,032 \\
\hline
\end{tabular}

Tabel 3. Hasil Perhitungan Tinggi Tenggelam Pelat Beton Apung dengan Bentuk Penopang Segitiga Dua Arah

\begin{tabular}{cccccccccc}
\hline Sudut & $\boldsymbol{\rho}_{\boldsymbol{b}}$ & $\boldsymbol{\rho}_{\boldsymbol{a}}$ & $\boldsymbol{g}$ & $\boldsymbol{V}_{\boldsymbol{b}}$ & $\boldsymbol{V}_{\boldsymbol{b t}}$ & $\boldsymbol{V}_{\boldsymbol{b a}}$ & $\boldsymbol{t}$ & $\boldsymbol{H}$ & $\boldsymbol{d}$ \\
\hline$\left[{ }^{\mathbf{0}}\right]$ & {$\left[\mathbf{~ k g / \mathbf { m } ^ { \mathbf { 3 } } ]}\right.$} & {$\left[\mathbf{~ k g} / \mathbf{m}^{\mathbf{3}}\right]$} & {$\left[\mathbf{~} \mathbf{m} / \mathbf{s}^{\mathbf{2}}\right]$} & {$\left[\mathbf{m}^{\mathbf{3}}\right]$} & {$\left[\mathbf{m}^{\mathbf{3}}\right]$} & {$\left[\mathbf{m}^{\mathbf{3}}\right]$} & {$[\mathbf{m}]$} & {$[\mathbf{m}]$} & {$[\mathbf{m}]$} \\
\hline 15 & 600 & 1.000 & 9,81 & 5,615 & 3,369 & 2,246 & 0,187 & 0,602 & 0,415 \\
\hline 20 & 600 & 1.000 & 9,81 & 6,768 & 4,061 & 2,707 & 0,226 & 0,746 & 0,520 \\
\hline 25 & 600 & 1.000 & 9,81 & 7,996 & 4,797 & 3,198 & 0,266 & 0,899 & 0,633 \\
\hline 30 & 600 & 1.000 & 9,81 & 9,328 & 5,597 & 3,731 & 0,311 & 1,066 & 0,755 \\
\hline 35 & 600 & 1.000 & 9,81 & 10,803 & 6,482 & 4,321 & 0,360 & 1,253 & 0,893 \\
\hline 40 & 600 & 1.000 & 9,81 & 12,469 & 7,482 & 4,988 & 0,416 & 1,459 & 1,043 \\
\hline 45 & 600 & 1.000 & 9,81 & 14,400 & 8,640 & 5,760 & 0,480 & 1,700 & 1,220 \\
\hline
\end{tabular}

Tabel 4. Hasil Perhitungan Tinggi Tenggelam Pelat Beton Apung dengan Bentuk Penopang Trapesium Dua Arah

\begin{tabular}{cccccccccc}
\hline sudut & $\boldsymbol{\rho}_{\boldsymbol{b}}$ & $\boldsymbol{\rho}_{\boldsymbol{a}}$ & $\boldsymbol{g}$ & $\boldsymbol{V}_{\boldsymbol{b}}$ & $\boldsymbol{V}_{\boldsymbol{b} \boldsymbol{t}}$ & $\boldsymbol{V}_{\boldsymbol{b a}}$ & $\boldsymbol{t}$ & $\boldsymbol{H}$ & $\boldsymbol{d}$ \\
\hline$\left[{ }^{\mathbf{0}}\right]$ & {$\left[\mathbf{~ k g} / \mathbf{m}^{\mathbf{3}}\right]$} & {$\left[\mathbf{~ k g} / \mathbf{m}^{\mathbf{3}}\right]$} & {$\left[\mathbf{~ m} / \mathbf{s}^{\mathbf{2}}\right]$} & {$\left[\mathbf{m}^{\mathbf{3}}\right]$} & {$\left[\mathbf{m}^{\mathbf{3}}\right]$} & {$\left[\mathbf{m}^{\mathbf{3}}\right]$} & {$[\mathbf{m}]$} & {$[\mathbf{m}]$} & {$[\mathbf{m}]$} \\
\hline 15 & 600 & 1.000 & 9,81 & 4,715 & 2,829 & 1,886 & 0,157 & 0,522 & 0,364 \\
\hline 20 & 600 & 1.000 & 9,81 & 5,545 & 3,327 & 2,218 & 0,185 & 0,637 & 0,452 \\
\hline 25 & 600 & 1.000 & 9,81 & 6,429 & 3,858 & 2,572 & 0,214 & 0,760 & 0,545 \\
\hline 30 & 600 & 1.000 & 9,81 & 7,388 & 4,433 & 2,955 & 0,246 & 0,893 & 0,647 \\
\hline 35 & 600 & 1.000 & 9,81 & 8,449 & 5,070 & 3,380 & 0,282 & 1,040 & 0,759 \\
\hline 40 & 600 & 1.000 & 9,81 & 9,650 & 5,790 & 3,860 & 0,322 & 1,207 & 0,885 \\
\hline 45 & 600 & 1.000 & 9,81 & 11,004 & 6,624 & 4,416 & 0,368 & 1,400 & 1,032 \\
\hline
\end{tabular}


Tabel 5. Hasil Perhitungan Tinggi Tenggelam Pelat Beton Apung dengan Bentuk Penopang Lengkung Dua Arah

\begin{tabular}{cccccccccc}
\hline Tinggi & $\boldsymbol{\rho}_{\boldsymbol{b}}$ & $\boldsymbol{\rho}_{\boldsymbol{a}}$ & $\boldsymbol{g}$ & $\boldsymbol{V}_{\boldsymbol{b}}$ & $\boldsymbol{V}_{\boldsymbol{b t}}$ & $\boldsymbol{V}_{\boldsymbol{b a}}$ & $\boldsymbol{t}$ & $\boldsymbol{H}$ & $\boldsymbol{d}$ \\
\hline$[\mathbf{c m}]$ & {$\left[\mathbf{k g} / \mathbf{m}^{\mathbf{3}}\right]$} & {$\left[\mathbf{~ k g} / \mathbf{m}^{\mathbf{3}}\right]$} & {$\left[\mathbf{~ m} / \mathbf{s}^{\mathbf{2}}\right]$} & {$\left[\mathbf{m}^{\mathbf{3}}\right]$} & {$\left[\mathbf{m}^{\mathbf{3}}\right]$} & {$\left[\mathbf{m}^{\mathbf{3}}\right]$} & {$[\mathbf{m}]$} & {$[\mathbf{m}]$} & {$[\mathbf{m}]$} \\
\hline 50 & 600 & 1.000 & 9,81 & 7,4504 & 4,470 & 2,980 & 0,248 & 0,700 & 0,452 \\
\hline 75 & 600 & 1.000 & 9,81 & 10,064 & 6,038 & 4,025 & 0,336 & 0,950 & 0,615 \\
\hline 100 & 600 & 1.000 & 9,81 & 12,768 & 7,661 & 5,107 & 0,426 & 1,200 & 0,774 \\
\hline
\end{tabular}

\subsection{Perhitungan Menggunakan Software Ansys}

Pelat betong apung dengan bentuk penopang satu arah dimodelkan menggunakan aplikasi Ansys dengan perlakuan sebagai berikut:

1. Pelat diletakkan pada pondasi elastis dengan elastic support sebesar $10 \mathrm{kN} / \mathrm{m}^{3}$ pada penampang sisi bawah penopang pelat.

2. Pelat dibebani $P=2.500 \mathrm{~N}$ pada ujung pelat.

3. Pelat diberikan tambahan $\mathrm{ES}=0,15 \mathrm{~N} / \mathrm{m}^{3}$ pada setiap sisinya.

Pelat dengan bentuk penopang satu arah seperti disajikan baik pada Gambar 6 dan Gambar 7 maupun Tabel $\mathbf{6}$ dan Tabel $\mathbf{7}$ mengalami deformasi yang berlebihan sehingga mengakibatkan pelat menjadi tidak stabil. Oleh karena itu, setiap pelat beton apung dengan bentuk penopang satu arah perlu diberikan tambahan elastic support pada setiap sisi, diasumsikan pelat beton apung tersebut mengalami jepit pada setiap sisinya.

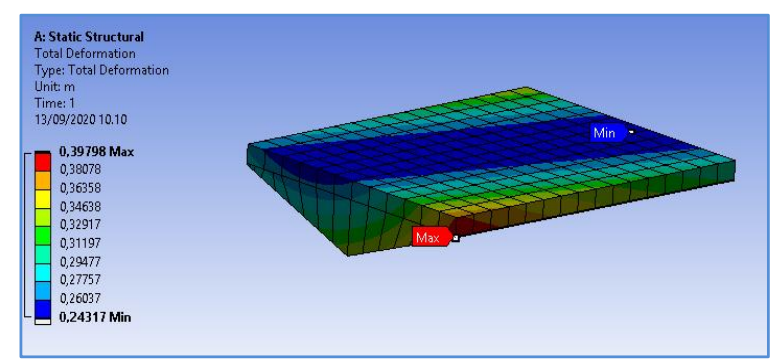

Gambar 6. Total deformasi pelat beton apung dengan bentuk penopang segitiga satu arah

Tabel 6. Dimensi dan Total Deformasi Pelat Beton Apung dengan Bentuk Penopang Segitiga Satu Arah

\begin{tabular}{ccccccc}
\hline Sudut & $\begin{array}{c}\text { Lebar } \\
\text { Pelat }\end{array}$ & $\begin{array}{c}\text { Panjang } \\
\text { Pelat }\end{array}$ & $\begin{array}{c}\text { Tebal } \\
\text { Pelat }\end{array}$ & $\begin{array}{c}\text { Tinggi } \\
\text { Penopang }\end{array}$ & \multicolumn{2}{c}{ Deformasi Total } \\
\hline$\left[{ }^{\mathbf{}}\right]$ & {$[\mathbf{c m}]$} & {$[\mathbf{c m}]$} & {$[\mathbf{c m}]$} & {$[\mathbf{c m}]$} & Max $[\mathbf{m}]$ & Min $[\mathbf{m}]$ \\
\hline 15 & 300 & 400 & 20 & 40,19 & 0,499 & 0,361 \\
\hline 20 & 300 & 400 & 20 & 54,6 & 0,398 & 0,243 \\
\hline 25 & 300 & 400 & 20 & 69,95 & 0,344 & 0,145 \\
\hline 30 & 300 & 400 & 20 & 86,6 & 0,325 & 0,115 \\
\hline 35 & 300 & 400 & 20 & 105,03 & 0,296 & 0,042 \\
\hline 40 & 300 & 400 & 20 & 125,86 & 0,291 & 0,074 \\
\hline 45 & 300 & 400 & 20 & 150 & 0,277 & 0,052 \\
\hline
\end{tabular}

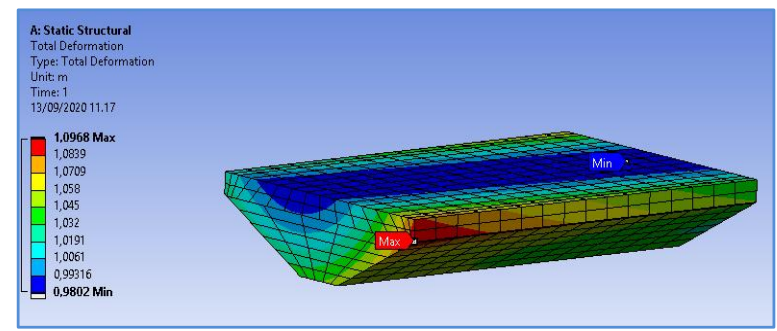

Gambar 7. Total deformasi pelat beton apung dengan bentuk penopang trapesium satu arah 
Tabel 7. Dimensi dan Total Deformasi Pelat Beton Apung dengan Bentuk Penopang Trapesium Satu Arah

\begin{tabular}{ccccccc}
\hline Sudut & $\begin{array}{c}\text { Lebar } \\
\text { Pelat }\end{array}$ & $\begin{array}{c}\text { Panjang } \\
\text { Pelat }\end{array}$ & $\begin{array}{c}\text { Tebal } \\
\text { Pelat }\end{array}$ & $\begin{array}{c}\text { Tinggi } \\
\text { Penopang }\end{array}$ & \multicolumn{2}{c}{ Deformasi Total } \\
\hline$\left[{ }^{\mathbf{}}\right]$ & {$[\mathbf{c m}]$} & {$[\mathbf{c m}]$} & {$[\mathbf{c m}]$} & {$[\mathbf{c m}]$} & Max $[\mathbf{m}]$ & Min $[\mathbf{m}]$ \\
\hline 15 & 300 & 400 & 20 & 32,15 & 1,075 & 0,896 \\
\hline 20 & 300 & 400 & 20 & 43,68 & 0,765 & 0,551 \\
\hline 25 & 300 & 400 & 20 & 55,96 & 1,097 & 0,980 \\
\hline 30 & 300 & 400 & 20 & 69,28 & 0,556 & 0,254 \\
\hline 35 & 300 & 400 & 20 & 84,02 & 0,535 & 0,251 \\
\hline 40 & 300 & 400 & 20 & 100,69 & 0,524 & 0,291 \\
\hline 45 & 300 & 400 & 20 & 120 & 0,393 & 0,077 \\
\hline
\end{tabular}

Pelat beton apung dengan bentuk penopang persegi seperti terlihat pada Gambar 8 dan Tabel 8 dimodelkan menggunakan software Ansys dengan perlakuan penambahan elastic supportsebesar $0,50 \mathrm{~N} / \mathrm{m}^{3}$ pada setiap sisi karena pelat beton apung tidak stabil. Pelat beton apung diasumsikan mengalami jepit pada setiap sisinya.

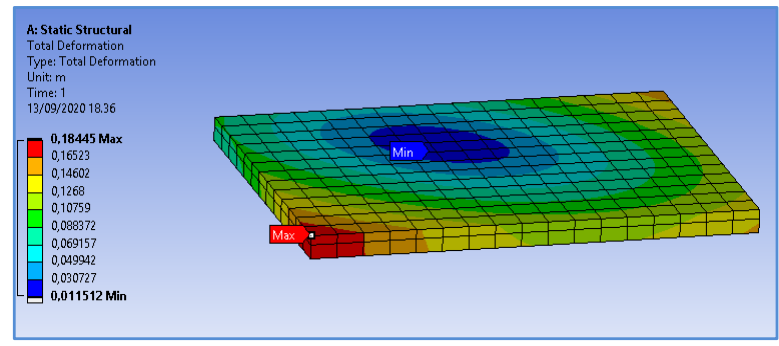

Gambar 8. Total deformasi pelat beton apung persegi

Tabel 8. Dimensi dan Nilai Deformasi Pelat Beton Apung Persegi

\begin{tabular}{ccccc}
\hline Lebar Pelat & Panjang Pelat & Tebal Pelat & \multicolumn{2}{c}{ Deformasi Total } \\
\hline$[\mathbf{c m}]$ & {$[\mathbf{c m}]$} & {$[\mathbf{c m}]$} & Max $[\mathbf{m}]$ & Min $[\mathbf{m}]$ \\
\hline 300 & 400 & 20 & 0,1845 & 0,0115 \\
\hline
\end{tabular}

Pelat beton apung dengan bentuk penopang dua arah seperti terlihat baik pada Gambar 9 hingga Gambar 11 maupun Tabel 9 hingga Tabel 11. dapat menghasilkan nilai deformasi total tanpa harus diberikan tambahan elastic support pada setiap sisinya sehingga pelat ini lebih stabil dibandingkan dengan pelat beton apung dengan bentuk penopang persegi dan juga pelat beton apung dengan bentuk penopang satu arah.

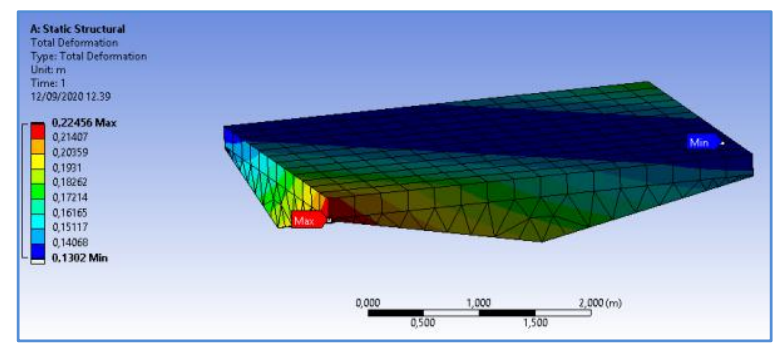

Gambar 9. Total deformasi pelat beton apung dengan bentuk penopang segitiga dua arah 
Tabel 9. Dimensi dan Nilai Deformasi Pelat Beton Apung dengan Bentuk Penopang Segitiga Dua Arah

\begin{tabular}{ccccccc}
\hline Sudut & $\begin{array}{c}\text { Lebar } \\
\text { Pelat }\end{array}$ & $\begin{array}{c}\text { Panjang } \\
\text { Pelat }\end{array}$ & $\begin{array}{c}\text { Tebal } \\
\text { Pelat }\end{array}$ & $\begin{array}{c}\text { Tinggi } \\
\text { Penopang }\end{array}$ & \multicolumn{2}{c}{ Deformasi Total } \\
\hline$\left[{ }^{\mathbf{}}\right]$ & {$[\mathbf{c m}]$} & {$[\mathbf{c m}]$} & {$[\mathbf{c m}]$} & {$[\mathbf{c m}]$} & Max [m] & Min [m] \\
\hline 15 & 300 & 400 & 20 & 40,19 & 0,225 & 0,130 \\
\hline 20 & 300 & 400 & 20 & 54,6 & 0,201 & 0,084 \\
\hline 25 & 300 & 400 & 20 & 69,95 & 0,194 & 0,053 \\
\hline 30 & 300 & 400 & 20 & 86,6 & 0,194 & 0,031 \\
\hline 35 & 300 & 400 & 20 & 105,03 & 0,198 & 0,019 \\
\hline 40 & 300 & 400 & 20 & 125,86 & 0,206 & 0,016 \\
\hline 45 & 300 & 400 & 20 & 150 & 0,216 & 0,014 \\
\hline
\end{tabular}

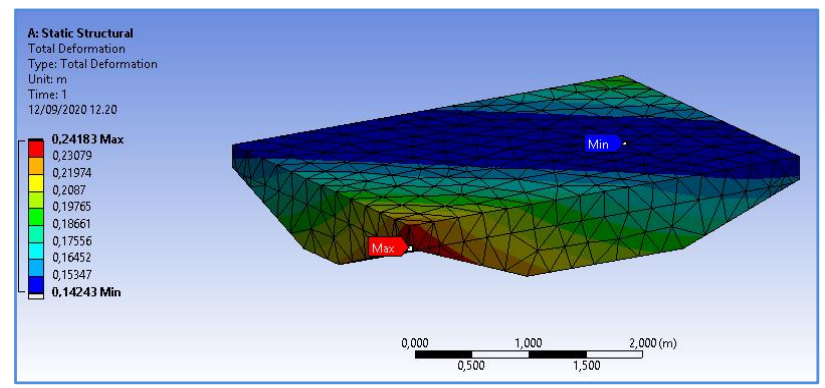

Gambar 10. Total deformasi pelat beton apung dengan bentuk penopang trapesium dua arah

Tabel 10. Dimensi dan Nilai Deformasi Pelat dengan Penopang Trapesium Dua Arah

\begin{tabular}{cccccccc}
\hline Sudut & Bentang $\mathbf{3}$ meter & \multicolumn{2}{c}{ Bentang $\mathbf{4}$ meter } & $\begin{array}{c}\text { Tinggi } \\
\text { Penopang }\end{array}$ & \multicolumn{2}{c}{ Deformasi Total } \\
\hline$\left[{ }^{\mathbf{0}}\right]$ & $\mathbf{B 1}[\mathbf{c m}]$ & $\mathbf{B 2}[\mathbf{c m}]$ & $\mathbf{B 1}[\mathbf{c m}]$ & $\mathbf{B 2}[\mathbf{c m}]$ & {$[\mathbf{c m}]$} & $\mathbf{M a x}[\mathbf{m}]$ & $\mathbf{M i n}[\mathbf{m}]$ \\
\hline 15 & 300 & 60 & 400 & 160 & 32,15 & 0,285 & 0,207 \\
\hline 20 & 300 & 60 & 400 & 160 & 43,68 & 0,242 & 0,142 \\
\hline 25 & 300 & 60 & 400 & 160 & 55,96 & 0,222 & 0,101 \\
\hline 30 & 300 & 60 & 400 & 160 & 69,28 & 0,213 & 0,069 \\
\hline 35 & 300 & 60 & 400 & 160 & 84,02 & 0,212 & 0,045 \\
\hline 40 & 300 & 60 & 400 & 160 & 100,69 & 0,213 & 0,026 \\
\hline 45 & 300 & 60 & 400 & 160 & 120 & 0,218 & 0,019 \\
\hline
\end{tabular}

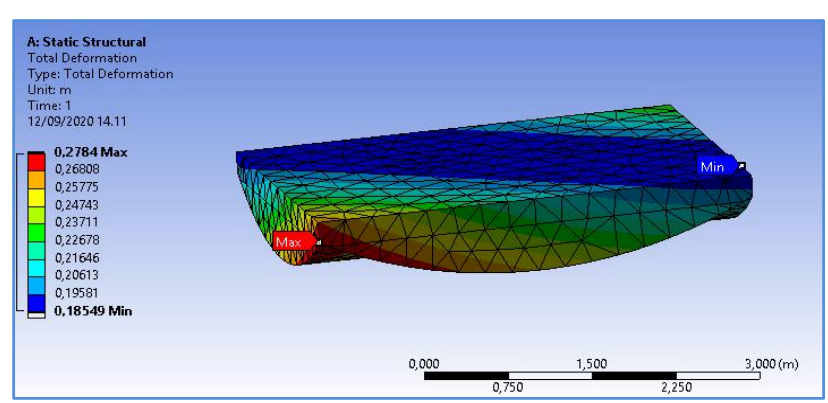

Gambar 11.Total deformasi pelat beton apung dengan bentuk penopang lengkung dua arah

Tabel 11. Dimensi dan Nilai Deformasi Pelat Beton Apung dengan Bentuk Penopang Lengkung Dua Arah

\begin{tabular}{cccccc}
\hline $\begin{array}{c}\text { Lebar } \\
\text { Pelat }\end{array}$ & $\begin{array}{c}\text { Panjang } \\
\text { Pelat }\end{array}$ & $\begin{array}{c}\text { Tebal } \\
\text { Pelat }\end{array}$ & $\begin{array}{c}\text { Tinggi } \\
\text { Penopang }\end{array}$ & \multicolumn{2}{c}{ Deformasi Total } \\
\hline$[\mathbf{c m}]$ & {$[\mathbf{c m}]$} & {$[\mathbf{c m}]$} & {$[\mathbf{c m}]$} & Max $[\mathbf{m}]$ & Min [m] \\
\hline 300 & 400 & 20 & 50 & 0,278 & 0,185 \\
\hline 300 & 400 & 20 & 75 & 0,236 & 0,109 \\
\hline 300 & 400 & 20 & 100 & 0,223 & 0,065 \\
\hline
\end{tabular}




\subsection{Perhitungan Teoritis Setelah Pelat Beton Apung Dibebani}

Adapun tujuan perhitungan teoritis yaitu untuk mengetahui keseimbangan apung pelat beton apung setelah dibebani oleh beban $\mathrm{P}=2.500 \mathrm{~N}$ dan mengalami deformasi berdasarkan datadata perencanaan.

Tabel 12. Keseimbangan Apung Pelat Beton Apung dengan Bentuk Penopang Segitiga Dua Arah

\begin{tabular}{ccccccccccc}
\hline Sudut & $\boldsymbol{V}_{\boldsymbol{b}}$ & $\boldsymbol{V}_{\boldsymbol{b t}}$ & $\boldsymbol{H}$ & $\boldsymbol{d}$ & $\boldsymbol{O G}$ & $\boldsymbol{O B}$ & $\boldsymbol{B G}$ & $\boldsymbol{I}_{\mathbf{0}}$ & $\boldsymbol{B} \boldsymbol{M}$ \\
\hline$\left[{ }^{\mathbf{0}}\right]$ & {$\left[\mathbf{m}^{\mathbf{3}}\right]$} & {$\left[\mathbf{m}^{\mathbf{3}}\right]$} & {$[\mathbf{m}]$} & {$[\mathbf{m}]$} & {$[\mathbf{m}]$} & {$[\mathbf{m}]$} & {$[\mathbf{m}]$} & {$\left[\mathbf{m}^{\mathbf{4}}\right]$} & {$[\mathbf{m}]$} & $\boldsymbol{G M}$ \\
\hline 15 & 5,615 & 4,635 & 0,602 & 0,638 & 0,387 & 0,347 & 0,039 & 9,011 & 1,944 & 1,905 \\
\hline 20 & 6,768 & 5,174 & 0,746 & 0,720 & 0,486 & 0,413 & 0,073 & 9,003 & 1,740 & 1,667 \\
\hline 25 & 7,996 & 5,725 & 0,899 & 0,825 & 0,593 & 0,485 & 0,108 & 8,842 & 1,544 & 1,436 \\
\hline 30 & 9,328 & 6,324 & 1,066 & 0,946 & 0,702 & 0,558 & 0,143 & 8,613 & 1,362 & 1,218 \\
\hline 35 & 1,803 & 3,554 & 1,253 & 1,042 & 0,854 & 0,507 & 0,346 & 6,347 & 1,786 & 1,440 \\
\hline 40 & 12,469 & 6,777 & 1,459 & 1,234 & 0,975 & 0,687 & 0,288 & 7,609 & 1,123 & 0,835 \\
\hline 45 & 14,400 & 9,440 & 1,700 & 1,431 & 1,134 & 0,866 & 0,268 & 8,444 & 0,894 & 0,626 \\
\hline
\end{tabular}

Berdasarkan Tabel 12 maka semua pelat dengan bentuk penopang lengkung dua arah adalah stabil karena nilai GM atau tinggi metasentrum yang didapatkan dari hasil perhitungan adalah positif $(+)$ atau $G M>0$, sehingga pelat tersebut akan tetap stabil apabila dibebani sentris maupun eksentris.

Berdasarkan perhitungan teoritis dan juga perhitungan menggunakan software Ansys didapatkan beberapa data pelat betong apung dengan bentuk penopang dua arah yang mengalami deformasi maksimum terkecil pada setiap bentuk penopangnya seperti pada Tabel 13.

Tabel 13. Perbandingan Pelat Betong Apung dengan Variasi Bentuk Penopang Dua Arah

\begin{tabular}{lccccc}
\hline Bentuk Penopang & $\begin{array}{c}\text { Volume } \\
\text { benda }\end{array}$ & $\begin{array}{c}\text { Deformasi } \\
\text { max }\end{array}$ & \multicolumn{2}{c}{ Draft $(\boldsymbol{d})$} & Deviasi \\
\cline { 2 - 6 } & {$\left[\mathbf{m}^{\mathbf{3}}\right]$} & {$[\mathbf{m}]$} & $\begin{array}{c}\text { Sebelum } \\
\text { dibebani }[\mathbf{m}]\end{array}$ & $\begin{array}{c}\text { Setelah } \\
\text { dibebani }[\mathrm{m}]\end{array}$ & {$[\mathbf{m}]$} \\
\hline Trapesium $35^{\circ}$ & 10,869 & 0,211 & 0,678 & 0,887 & 0,209 \\
\hline Lengkung $100 \mathrm{~cm}$ & 12,768 & 0,223 & 0,774 & 0,995 & 0,220 \\
\hline Segitiga $30^{\circ}$ & 9,328 & 0,194 & 0,755 & 0,946 & 0,191 \\
\hline
\end{tabular}

\section{KESIMPULAN}

Berdasarkan hasil analisis dan pembahasan didapatkan kesimpulan sebagai berikut:

1. Semakin besar ukuran dimensi penampang pelat beton apung belum tentu pelat beton apung akan semakin stabil dan menghasilkan nilai deformasi yang kecil.

2. Dalam penelitian ini bentuk penopang pelat beton apung yang paling sesuai dengan keseimbangan apung adalah pelat beton apung dengan bentuk penopang dua arah, karena pelat beton apung ini memiliki bentuk penopang yang sama pada setiap sisinya sehingga pelat beton apung akan mendapatkan tekanan air yang sama besar pada setiap sisinya. Pelat beton apung juga akan tetap stabil meskipun dibebani eksentris.

3. Pelat beton apung yang paling sesuai dengan keseimbangan apung dan paling stabil serta efisien adalah pelat beton apung dengan bentuk penopang segitiga $30^{\circ}$ dua arah. Hal ini dikarenakan pelat beton apung tersebut menghasilkan nilai deformasi terkecil sebesar $0,194 \mathrm{~m}$; volume pelat terkecil sebesar 9,328 $\mathrm{m}^{3}$ serta deviasi tinggi benda tenggelam (draft) terkecil yaitu 0,191 $\mathrm{m}$ di antara pelat beton apung dengan bentuk penopang dua arah lainnya. 


\section{DAFTAR RUJUKAN}

Badan Standardisasi Nasional. (2002). SNI 03-2847-2002 tentang Tata Cara Perhitungan Struktur Beton Untuk Bangunan Gedung. Bandung: Badan Standardisasi Nasional.

Callister, W. (1997). Materials Science and Engineering - An Introduction. John Willey and Sons, Inc.

Nastain, S.T.,M.T. (2005). Google. Dipetik Agustus 30, 2020, dari Academia: https://www.academia.edu/6347762/MEKANIKA_FLUIDA

Undang-Undang Republik Indonesia Nomor 17 Tahun 2008. (2008). UU RI No.17 Tahun 2008 Tentang Pelayaran, Pasal 1 angka 36. 